\title{
The Viability of Deferred Prosecution Agreements (DPAs) in the UK: The Impact on Global Anti-Bribery Compliance
}

\section{Qingxiu $\mathrm{Bu}^{1}$}

Accepted: 7 January 2021 / Published online: 2 February 2021

(c) The Author(s) 2021

\begin{abstract}
Deferred prosecution agreements (DPAs) provide an alternative enforcement tool to tackle economic crime. Prosecutors tailor punishment and remediation measures more accurately to satisfy the principles of prosecution. The companies in question can avoid criminal charges, provided that they comply with agreed terms and conditions. The use of DPAs is conducive to relieving collateral consequences, while being able to deter, punish and reshape corporate behaviour. In principle, enforcement authorities can maximise the leverage with criminal liability over companies to cultivate a robust corporate culture against bribery. It is argued that an effective global anti-bribery regime rests with not only transnational cooperation, but also adequate governance and rigorous compliance. With the DPAs having increased in prominence as a mainstay of the US enforcement regime, it remains to be seen whether the potent tool will be viable and further reshape the future enforcement landscape of the anti-bribery regime in the UK and even on a global basis.
\end{abstract}

Keywords Multinational company (MNC) · Corporate criminal liability · Antibribery $\cdot$ Deferred prosecution agreement (DPA) $\cdot$ Global settlement

\section{Introduction}

Bribery represents a serious impediment to multinational companies (MNCs)' governance integrity and fair competition in the global market. ${ }^{1}$ An eruption of highprofile scandals has triggered anti-bribery enforcement agencies to strengthen their

\footnotetext{
1 Schipani et al. (2016), p 63.
}

Qingxiu Bu

q.bu@sussex.ac.uk

1 Associate Professor, Sussex Law School, University of Sussex, Falmer, UK 
policing of corporate behaviour. ${ }^{2}$ The prevalent bribery of foreign officials has prompted legislation, ${ }^{3}$ which also suggests the need for more effective law enforcement to crack down on the unlawful conduct. ${ }^{4}$ Considered as the toughest legislation on bribery in the world, the Bribery Act (BA 2010) helps to sustain increased global enforcement of anti-bribery laws. For the sake of saving precious juridical resources on the one hand, and attenuating adverse collateral effects arising from criminal liability on the other, the UK introduced a framework of deferred prosecution agreements (DPAs) through the Crime and Courts Act 2013. ${ }^{5}$ With the DPAs being effective from 24 February 2014, the Serious Fraud Office (SFO) and the Director of Public Prosecutions (DPPs) have the power to offer and enter into DPAs subject to the court's approval. It represents a critical weapon to resolve allegations of corporate crime. As a discretionary tool, a DPA is reached between prosecutors and defendants where the latter are accused of bribery. It involves the suspension of a criminal indictment for an agreed period, in exchange for the defendant fulfilling certain agreed conditions. ${ }^{6}$ The final approval of a DPA will rest with the court. The prosecutor will notify the court that the suspended criminal proceedings should be discontinued on the condition that the defendant has satisfied the terms and conditions once a DPA expires. ${ }^{7}$ Should there be any breach, the court can bring it to an end leaving the SFO to proceed with a criminal prosecution. ${ }^{8}$ Corporations can thus avoid the stigma of a criminal conviction and the collateral consequences that a prosecution may bring, but are still effectively punished for their crimes. ${ }^{9}$ Given that the use of DPAs reflects a shift towards a more US-style approach, the paper examines whether the distinct UK-based DPAs will represent an effective alternative to corporate criminal enforcement. ${ }^{10}$ Proceeding in five parts, the paper explores whether DPAs would play a constructive role in reshaping the UK and even the global anti-bribery landscape. Section 2 starts with an introduction to DPAs in the context of tackling global economic crime. The collateral consequences of subjecting companies to a criminal prosecution can be devastating, which partly justifies

\footnotetext{
2 Securities Exchange Commission (SEC), SEC Charges Siemens AG for Engaging in Worldwide Bribery (15 December 2008), http://www.sec.gov/news/press/2008/2008-294.htm; DoJ, Siemens AG and Three Subsidiaries Plead Guilty to Foreign Corrupt Practices Act Violations and Agree to Pay \$450 Million in Combined Criminal Fines. Coordinated Enforcement Actions by DOJ, SEC and German Authorities Result in Penalties of \$1.6 Billion (15 December 2008), http://www.justice.gov/opa/pr/2008/Decem ber/08-crm-1105.html; Coffee (1981), p 386.

3 Foreign Corrupt Practices Act (FCPA), 15 USC $\S \S 78 m, 780,78 d d-1$ to -3 (2006 \& Supp. IV 2011); UK Bribery Act 2010; PRC Criminal Law (Amendment 2011), Art. 164; Perkel (2003), p 683.

4 Hasnas (2007), p 1269.

5 Crime and Courts Act 2013, s. 45; The Crime and Courts Act 2013 (the Act) received Royal Assent on 25 April 2013.

${ }^{6}$ Crime and Courts Act 2013, Schedule 17.

7 SFO, Deferred Prosecution Agreements Code of Practice Crime and Courts Act 2013 (11 February 2014), https://www.cps.gov.uk/publications/directors_guidance/dpa_cop.pdf ('SFO, DPA 2014'), § 14.5.

8 UK Ministry of Justice, Deferred Prosecution Agreements: Government Response to the Consultation on a New Enforcement Tool to Deal with Economic Crime Committed by Commercial Organisations CP(R)18/2012 (23 October 2012), https://www.gov.uk/government/uploads/system/uploads/attachment _data/file/236000/8463.pdf.

$\overline{9}$ Alschuler (2009), p 1359.

${ }^{10}$ George et al. (2014), p 115.
} 
the legitimacy of the innovative approach. To a great extent, the deterrent tool's efficiency in combating bribery relies on a credible threat of prosecution. Section 3 discusses the evolving framework under which the court plays significant but controversial roles in overseeing the DPAs. A crucial question lies in the degree of judicial oversight and the mechanism for achieving the goal. Section 4 looks into challenges through a case study, demonstrating that the functionally equivalent approach results inevitably in divergence in enforcement practices, despite the legal convergence between jurisdictions. This part analyses whether a single global settlement via DPAs is viable and considers how to cater for trans-jurisdictional matters and to level the international playing field. Some practical impediments stand in the way of achieving the desired goal, such as an issue of double jeopardy. Section 5 proposes how an MNC can effectively avoid exposure to multiple jurisdictions through enhancing internal governance. It is vital to implement a global anti-bribery compliance programme with particular regard to due diligence. A conclusion is given based on the above discussion in Sect. 6.

\section{Prosecution's Collateral Consequences vis-à-vis DPAs' Virtues}

Criminal prosecutions are not always an ideal mechanism to pursue wrongdoers, ${ }^{11}$ given that collateral consequences are sometimes immense and even harm innocent parties. ${ }^{12}$ The reputational damage and potential follow-on litigation may cause credit downgrades as a result of deteriorating financial health. ${ }^{13}$ While reshaping corporate behaviour, DPAs enable MNCs to avoid such catastrophic effects. Two goals can be achieved through incentivising responsible corporate behaviour while mitigating adverse collateral effects. ${ }^{14}$ It is of the utmost significance to pursue a legitimate avoidance of the risks arising from organisational indictment and alleviate further uncertainties of trials. ${ }^{15}$

\subsection{Collateral Consequences of Corporate Prosecutions}

Prosecutors are increasingly concerned with catastrophic consequences resulting from bringing a bribery action to court. ${ }^{16} \mathrm{MNCs}$ may face devastating debarment, the so-called corporate death sentence, or may even collapse. ${ }^{17}$ The potential damage could risk causing unjust harm to innocent parties. ${ }^{18}$ DPAs are designed to mitigate companies' further loss and protect those who have not been involved in

\footnotetext{
11 Arlen and Kraakman (1997), p 687.

12 'Corporate Crime: Regulating Corporate Behaviour through Criminal Sanctions Developments in the Law', Harv. Law Rev. 92(6):1227-1375 (1979).

13 Xiao (2013), p 233.

14 Markof (2013), p 797.

15 Crespo (2018), p 1303.

16 Nanda (2011), pp 63-89.

17 Grossman (2016), p 697.

18 Weissman and Newman (2007), p 411.
} 
the wrongdoing. The enforcement tool enables prosecutors to have an alternative tool to tackle bribery and ensure nearly the same punitive effects while avoiding the adverse results. ${ }^{19}$ It is worthy to note that the DPA mandate should not be justified merely because of the collateral consequences. ${ }^{20}$

\subsubsection{Debarment: Corporate Death Sentence}

Criminal prosecution could result in debarment from public procurement contracts, which is also known as a death penalty for a business. ${ }^{21}$ For instance, the Public Procurement Directive (2004/18/EC [2004] OJ L 134/114) of the EU mandates the exclusion of suppliers convicted of corruption. ${ }^{22}$ Meanwhile, the procurement system would lose the opportunity to incentivise positive corporate behaviour. ${ }^{23}$ Debarment will drive corrupt activity further underground and even make it undetectable indefinitely, ${ }^{24}$ since it discourages companies from engaging in voluntary disclosure to enforcement authorities. ${ }^{25}$ Criminal liability considerably weakens the principal's threat to self-report bribery because of such a strong disincentive. Even though a DPA disposing of bribery offences does not trigger mandatory exclusion but may trigger discretionary exclusion in the $\mathrm{UK},{ }^{26}$ the chilling effect undermines counterproductively the deterrence. As such, threats by a corporation to take such preventive action will fail to deter the agent's future bribery. ${ }^{27}$ This echoes Arlen and Kraakman's finding that the undesired consequence compromises the deterrence of the internal safeguarding measures. ${ }^{28}$ The EU Public Procurement Directive 2014 softens the rules on debarment, which may, to some extent, mitigate the debarment risk. ${ }^{29}$ It still remains a dilemma whether to self-disclose unlawful conduct.

\subsection{2 (Un)just Harm for an Innocent Party}

A guilty plea entails severe collateral consequences for innocent third parties and delays prompt the restitution of victims. ${ }^{30}$ Harm extends beyond an entity in question

\footnotetext{
19 Alexander and Cohen (2015), p 537.

20 Arlen and Kahan (2016), p 323.

21 Markof (2013), p 797; Tillipman (2012), p 49.

22 The Directive requires that contractors that are convicted by a final judgement of any of the following crimes be debarred from public procurement: (1) participating in a criminal organisation; (2) corruption;

(3) fraud; or (4) money laundering.

23 Tillipman (2012), p 49.

24 Kaal and Lacine (2013), p 61.

25 Stevenson and Wagoner (2011), p 775.

26 UK Public Contracts Regulations 2015 (SI2015/102); OCG Guidance on the Mandatory Exclusion of Economic Operators, 2010.

27 Arlen and Kraakman (1997), p 687.

28 Arlen and Kraakman (1997), p 687.

29 EU Directive 2014/24 on public procurement [2014] OJ L 94/65 was implemented in the UK by the Public Contracts Regulations 2015 on 26 February 2015.

30 Arlen and Kraakman (1997), p 687.
} 
to its shareholders, other stakeholders and even the wider economy. ${ }^{31}$ Their interests may be affected by large fines and an enormous compliance expense, including the costly corporate monitorship. ${ }^{32}$ As Alschuler observed, 'the embarrassment of corporate criminal liability is that it punishes the innocent along with the guilty' ${ }^{33} \mathrm{~A}$ plausible issue arises as to whether shareholders should be viewed as an innocent party. They are, in principle, responsible for corporate wrongdoing since they have the power to choose corporate management. ${ }^{34}$ In the arena of corporate governance, shareholders normally take financial risks whenever they invest. ${ }^{35}$ Criminal liability is one of the assumed investment risks prior to the purchase of corporate stock. ${ }^{36}$ Shareholders will also indirectly benefit virtually from illicit gains, provided that the bribery goes undetected. ${ }^{37}$ Otherwise, they are required merely to surrender unjust enrichment, when the corporation is forced to disgorge illicit profits. ${ }^{38}$ Shareholders are not penalised in substance, and collateral risks are thus not adequately justifiable for DPAs as opposed to prosecution in this regard. ${ }^{39}$ Despite the argument surrounding shareholders, prosecutors have long recognised the profound collateral consequences, which leads them to act with great deliberation in criminalising corporate behaviour. $^{40}$

\subsubsection{Positive and Negative Effect: Weighing the Gains and Losses}

Corporations are sensitive to the expected cost of bribery. Whether or not to selfreport remains a complex balancing decision. In October 2016, Walmart purportedly rejected a proposal to pay $\$ 600$ million to settle an FCPA investigation. ${ }^{41}$ It has finally spent $\$ 840$ million on the investigation into its compliance failures, which took enforcement agencies nearly 6 years. ${ }^{42}$ Apparently, neither the corporate defendant nor the prosecutor wins in substance in such a lengthy process. The frequency of prosecution has declined particularly against those high-profile corporations. ${ }^{43}$ Although a criminal conviction has a destabilising effect, MNCs should by no means rely on the negative effect in an effort to avoid prosecution. ${ }^{44}$ Any defence based on collateral consequences must be subjected to increased scrutiny. The court

\footnotetext{
31 McLean (2012), p 1970.

32 Beale (2009), p 1481.

33 Alschuler (2009), p 1359.

34 Alschuler (2009), p 1359.

35 Macey (1991), p 315.

36 Kennedy (1985), p 443.

37 Macey (1991), p 315.

38 SFO, Shareholder Agrees Civil Recovery by SFO in Mabey \& Johnson (13 January 2012), http:// www.sfo.gov.uk/press-room/latest-press-releases/press-releases-2012/shareholder-agrees-civil-recoveryby-sfo-in-mabey--johnson.aspx.

39 Markof (2013), p 797.

40 Kaal and Lacine (2013), p 61; Paulsen (2007), p 1434.

41 Addady (2016).

42 Viswanatha and Nassauer (2017).

43 Garrett (2011), p 1775.

${ }^{44}$ Garrett (2016), pp 1-18.
} 
also balances the equities at issue, weighing the DPA's costs and benefits. ${ }^{45}$ In this vein, DPAs are valuable alternatives, whose potential settlement appeals simply to avoid the cost and uncertainty of a trial. ${ }^{46}$ It is worth examining whether DPAs are appropriate to resolve the allegation in the UK.

\subsection{Transplanting DPAs into the UK Enforcement System}

As discussed earlier, DPAs not only enable a company to avoid these financial repercussions and a reputational damage disaster scenario, but also have the same punitive and deterrent effect as a guilty plea. ${ }^{47}$ The Serious Fraud Office (SFO) uses DPAs to reach settlements with companies, whereby it agrees to suspend criminal proceedings provided that they can meet certain conditions. ${ }^{48} \mathrm{~A}$ defendant is typically required to admit guilt and pay significant fines, restitution and disgorgement of fees. ${ }^{49}$ A decision whether to enter into a DPA will rest with the Director of the SFO and the Director of Public Prosecutions. ${ }^{50}$

\subsubsection{The DPAs'Virtues}

DPAs incentivise corporations to establish an effective compliance programme, through which they could ultimately shield themselves from criminal liability. ${ }^{51}$ As a sword over the entities' head, DPAs strike a critical balance between penalty and deterrence, and minimise collateral consequences. ${ }^{52}$ Companies and prosecutors are thus allowed to resolve high-stakes claims of bribery through the formers' comprehensive cooperation and enhancement of rigorous compliance measures. ${ }^{53}$ The scheme helps to avoid reputational damage, lengthy investigations and uncertain proceedings. A DPA will not trigger mandatory debarment under the EU Public Procurement Regime, since it is not a criminal offence. ${ }^{54}$ The cost-efficient outcome through cooperation may justify the use of other routes as opposed to a criminal prosecution. ${ }^{55}$ The enforcement tool not only allays a financial burden, but also ensures that innocent parties are not unduly punished for corporate wrongdoing. ${ }^{56}$ The use of DPAs can free up precious judicial resources, enabling enforcement

\footnotetext{
45 Arlen and Kahan (2016), p 323.

46 Xiao (2013), p 233.

47 O’Sullivan (2014), p 29.

48 SFO, Deferred Prosecution Agreements: New Guidance for Prosecutors (14 February 2014), http:// www.sfo.gov.uk/press-room/latest-press-releases/press-releases-2014/deferred-prosecution-agreements -new-guidance-for-prosecutors.aspx ('SFO, DPAs New Guidance').

49 Lewis and Woodward (2014), p 923.

50 SFO, DPA 2014, § 2.1.

51 Werle (2019), p 1366.

52 Greenblum (2005), p 1863.

53 Cunningham (2014), p 1.

54 Arlen (2019).

55 Fisher et al. (2013), p 159.

56 Gilchrist (2012), p 1.
} 
authorities to investigate a higher proportion of bribery cases. ${ }^{57}$ By encouraging self-disclosure, the increasing detection of unlawful conduct leads to more corporate accountability. ${ }^{58}$ The number of FCPA investigations per year has increased tenfold in the US. ${ }^{59}$ A total of 209 settlements were entered into during 2005-2012 while only 21 had been reached during 2000-2004. ${ }^{60}$ Some high-profile agreements, like Siemens $A G$ in 2008 , demonstrate the efficacy of DPAs. ${ }^{61}$ Corporate crime would not have been able to be uncovered without this innovative enforcement tool. ${ }^{62}$ From the prosecutors' perspective, the uncertainties of a trial will be avoided as well, given the difficulty in meeting the high standard in establishing criminal liability.

\subsubsection{Inevitable Risks Accompanied by DPAs}

On the other side of the coin, there could be some unintended consequences with the use of DPAs. ${ }^{63}$ First, there will be a potential risk for shareholders if a company agrees to a substantial fine and costly compliance programmes in return for a DPA. ${ }^{64}$ Khanna observed that sometimes directors have little incentive to object to corporate criminal liability. ${ }^{65}$ Even in contravention of their fiduciary duty to promote the success of company, they may be inclined to prefer significant pecuniary penalties to the avoidance of other sanctions, including their own prosecution. ${ }^{66}$ Judge Kaplan held that: 'DPAs allow companies to avoid prosecution by paying a fine instead of forcing culpable individuals to "pay the price" for their criminal offences' ${ }^{67}$ Despite the seminal doctrine of a separate legal entity, it is individuals who commit crime for which a company is always responsible. The lack of individual prosecution creates a risk of insufficient deterrence and enforcement agencies need to ensure the adequacy of prosecution to attenuate the risks. ${ }^{68}$ Although the US has recently introduced the Ending Too Big to Jail Act to address the problem of executives not being held criminally liable for their offences, it remains to be seen whether the Act can show its teeth and bring those culpable individuals to accountability. ${ }^{69}$

\footnotetext{
57 Uhlmann (2013), p 1295.

58 Wilt (2016), p 61.

59 Weiss (2009), p 471.

60 Kaal and Lacine (2013), p 61.

61 SEC, SEC Charges Siemens AG for Engaging in Worldwide Bribery (15 December 2008), http:// www.sec.gov/news/press/2008/2008-294.htm; SEC, SEC Charges KBR and Halliburton for FCPA Violations (11 February 2009), http://www.sec.gov/news/press/2008/2008-294.htm; SEC, SEC Charges Seven Oil Services and Freight Forwarding Companies for Widespread Bribery of Customs Officials (4 November 2010), http://www.sec.gov/news/press/2010/2010-214.htm.

62 Bonneau (2011), p 365.

63 Bourjaily (2015), p 543.

64 Warin and Boutros (2007), p 121.

65 Khanna (1996), p 1477.

66 UK Companies Act (CA 2006) s. 172(1); Lewis and Woodward (2014), p 923.

67 United States v. U.S. Bancorp, No. 18-cr-150 (S.D.N.Y. Feb. 22, 2018), ECF No. 9.

68 Oded (2017), p 49.

69 The Act was introduced on 14 March 2018 (115th Congress, 2017-2019).
} 
Second, there is no guarantee that self-reporting will lead to non-prosecution. ${ }^{70}$ Neither will there be a guarantee for a DPA since the UK law entails more rigorous judicial oversight than its US counterpart. ${ }^{71}$ The US Department of Justice (DoJ) revised the FCPA Corporate Enforcement Policy that furthers uncertainty. ${ }^{72}$ Even so, this uncertainty should not be overread but interpreted dialectically, given the substantial challenges that the SFO faces due to the high threshold for establishing corporate criminal liability. As such, neither the DoJ nor the SFO guarantees a DPA based on self-reporting itself, which forms only part of the requirements that potentially qualify for the credit. Plausibly, preserving prosecution is essential to ensuring the exercise of justice. ${ }^{73}$ Whether to self-report has wide-reaching implications, and a company in question needs to balance the risks and potential benefits on a global basis.

Third, an MNC likely exposes itself to being potentially sued in multiple jurisdictions because of its self-incriminating admissions disclosed publicly in a DPA. In principle, any DPA must be made public so as to ensure transparency in the UK. ${ }^{74}$ Some prosecutors insist that a firm agrees not to dispute the facts and matters contained in the DPA as a prerequisite for the settlement. ${ }^{75}$ This request departs from a policy of 'Neither Admit Nor Deny' which is widely adopted by the DoJ and SEC. ${ }^{76}$ A common concern is that documents disclosed to an enforcement authority in which a company admits to bribery could prejudice potential litigation. ${ }^{77} \mathrm{~A}$ convicted entity may thus be subject to a follow-up civil action. ${ }^{78}$ This holds particularly true for those MNCs with a global presence. They could face prosecution in other jurisdictions, notably in the US where the doctrine of double jeopardy is more limited than in the UK. ${ }^{79}$ Plaintiffs can make use of the admissions in support of their claims, because a statement of facts is not binding in any other legal proceeding. ${ }^{80}$ Unless a double-jeopardy scenario is to be avoided, incentives for MNCs' self-disclosure will be considerably compromised. This makes it more difficult for

\footnotetext{
70 SFO, Corporate Self-Reporting (October 2012), https://www.sfo.gov.uk/publications/guidance-polic $\mathrm{y}$-and-protocols/corporate-self-reporting/; $R$ v. Skansen Interiors Limited (Southwark Crown Court 2018).

71 Pollard (2014).

72 DoJ, FCPA Corporate Enforcement Policy (November 2017; updated March 2019), https://www.justi ce.gov/criminal-fraud/file/838416/download.

73 US DoJ (2017). Vorenberg (1981), p 1521.

74 UK Ministry of Justice, Deferred Prosecution Agreements: Government Response to the Consultation on a New Enforcement Tool to Deal with Economic Crime Committed by Commercial Organisations CP(R)18/2012 (23 October 2012), https://www.gov.uk/government/uploads/system/uploads/attachment _data/file/236000/8463.pdf.

75 Garret (2017), p 1483.

76 Kaul (2015), p 535.

77 Boutros and Funk (2012), p 259.

78 Reilly (2015), p 1683.

79 Principato (2014), p 767.

80 SEC, Deferred Prosecution Agreement with Tenaris (May 2011), http://www.sec.gov/news/press /2011/2011-112-dpa.pdf.
} 
the entity to nurture a culture to assist regulators in detecting and sanctioning the bribery, and even to confess voluntarily to bribery. ${ }^{81}$

\subsection{Enhance Credibility in Forming DPAs: Credible Threats against Both Principals and Agents}

The DPAs' ultimate efficacy will be determined by the level of companies' willingness to engage and prosecutors' effective use of the enforcement tool. ${ }^{82}$ The latter has immense leverage during the negotiation of a DPA, because a criminal indictment has devastating consequences, including debarment, not to mention a drop in a company's stock price. ${ }^{83}$ DPAs are unlikely to be an effective tool to combat bribery unless there is a creditable threat of prosecution. ${ }^{84}$ Empty threats without effective sanctions carry little weight. Companies will not be deterred by a threat of prosecution as long as corporate fines remain trivial and the challenges of convicting an individual are substantial. ${ }^{85}$ The system will have to solve the credibility problem in order to induce an adequate deterrent regime. ${ }^{86}$

The law governing corporate enforcement remains generally inefficient, which justifies the induction of corporate policing. ${ }^{87}$ Companies are potential enforcers because they can intervene to help enforcement agencies investigate crime and convict individual wrongdoers. ${ }^{88}$ DPAs help to reduce bribery, but only to the extent that a company is able to credibly threaten to undertake certain compliance measures, ${ }^{89}$ including sanctions against its rogue employees. The enhanced disciplinary measures are thereby indispensable to improve internal controls. ${ }^{90}$ In terms of the efficacy of enforcement, it must be ensured that individuals who are tempted to commit bribery expect to be punished. In theory, the resultant credible threat of criminal liability spurs corporate efforts to prevent bribery, ${ }^{91}$ steering those companies in question to turn to a DPA. This hypothesis has been well proved in US v. Andersen, ${ }^{92}$ given the consequences of the decision by Arthur Andersen to reject the offer of a DPA in 2002. ${ }^{93}$ The Supreme Court unanimously reversed a trial court conviction that had

\footnotetext{
81 Security Exchange Commission (SEC) and Department of Justice (DoJ), A Resource Guide to the FCPA US Foreign Corrupt Practices Act (14 November 2012), https://www.justice.gov/sites/default/files/ criminal-fraud/legacy/2015/01/16/guide.pdf, p 30 (FCPA Guidance).

82 Arlen (2016), p 191.

83 Diskant (2008), p 126, Weissmann (2007), p 1319.

84 Arlen (2019).

85 'Corporate Crime: Regulating Corporate Behaviour through Criminal Sanctions Developments in the Law', Harv. Law Rev. 92(6):1227-1375 (1979).

86 Arlen and Kraakman (1997), p 687.

87 Arlen and Kahan (2016), p 323.

88 Braithwaite (1982), p 1466.

89 Arlen and Kraakman (1997), p 687.

90 Rose (2015b), Chapter II.

91 'Corporate Crime: Regulating Corporate Behaviour through Criminal Sanctions Developments in the Law', Harv. Law Rev. 92(6):1227-1375 (1979).

92 Buell (2011), p 87.

93 Greenblum (2005), p 1863; Weissmann (2007), p 1319.
} 
been upheld by the Fifth Circuit Court of Appeals, however. ${ }^{94}$ This case does not necessarily suggest that the existing DPA system can properly address the issue. Due to the high threshold for establishing corporate criminal liability, it remains to be seen whether companies will consider DPAs a worthy alternative to the threat of litigation. ${ }^{95}$ Vigorous enforcement and stringent penalties would help to achieve such goals between principals and agents, as well as prosecutors and corporations. ${ }^{96}$ Instituting DPAs into the UK not only provides the SFO and DPP with an option to avoid adverse results, but also considerably changes the way in which companies evaluate their strategic approaches upon the discovery of bribery. It is imperative for MNCs to take robust precautions to guard against bribery undertaken on their behalf, and to ensure that their anti-bribery programmes are adequately in place.

\section{Judicial Supervision of DPAs}

DPAs have become a mainstay of the US enforcement authorities' arsenal. The Securities Exchange Commission (SEC) and DoJ have expanded the use of this tool within the enforcement architecture and regularly reach a binding settlement. ${ }^{97}$ Ideally, DPAs should yield a result that is consistent with the goals including deterrence, remediation and punishment. ${ }^{98}$ The UK's early judicial involvement differs substantially from that of the US model. It is worth looking into the US' experiences in terms of the pros and cons concerning judicial oversight and ascertaining whether the divergence would affect the DPAs' viability in the UK.

\subsection{The Unsettled Issue of the Judicial Review of DPAs in the US}

The insufficient judicial oversight has caused substantial concerns as to the appropriateness of DPAs in the US. ${ }^{99}$ A critical challenge arises, given that the parties' agreement to proceeding with a DPA is entered into outside the court's purview. ${ }^{100}$ The system of DPAs seems to handicap the ability of the judiciary to be substantially involved in the referral process. ${ }^{101}$ Alleged firms have increasingly entered into DPAs and have settled out of court rather than being punitively prosecuted as guilty parties in the judicial system. ${ }^{102}$ A growing number of judges have been increasingly concerned about the issues of transparency and accountability. ${ }^{103}$ Greenblum highlights the difficulties in judicial involvement at the negotiation stage: '[...] even

\footnotetext{
94 Arthur Andersen LLP v. US, 544 US 696 (2005).

95 SFO, DPA 2014, § 1.1.

96 Anderson and Waggoner (2014).

97 Allen (2014), p 285.

98 Gallo and Greenfield (2014), p 525.

99 Kaal and Lacine (2013), p 61.

100 Weiss (2009), p 471.

101 Warin and Boutros (2007), p 121.

102 Miller (2016), p 135.

103 Golumbic and Lichy (2014), p 1293.
} 
after a deferral proposal is filed with the court for the judge's approval, no judge would have a substantive basis for altering its proposed terms given the lack of formal adversarial dispute between the parties'. ${ }^{104}$ The analysis of DPAs in the US demonstrates that the process is arbitrary, unpredictable and inconsistent. ${ }^{105}$ There should be greater judicial involvement in the entire DPA process and a firm commitment to transparency. ${ }^{106}$ As Silverglate said: 'cases generally are settled rather than tried before a judge, thus the government's view of the statute has been untested in the courts'. ${ }^{107}$ This raises another inquiry as to whether some companies are too big to be prosecuted. ${ }^{108}$ It is alleged that the prolific use of DPAs has created a prosecution-free zone for large banks on the ground that prosecuting large banks has the potential to destabilise the economy. ${ }^{109}$ There is even a perception that power is shifting away from the judiciary and into the hands of the DoJ. ${ }^{110}$ Upon this reasoning, DPAs should proceed by a waiver of indictment, confirmed in open court, and the filing of criminal information. ${ }^{111}$ It seems that DPAs have virtually led 'to a deplorable culture of cooperation'. ${ }^{112}$ These concerns have prompted further consideration of the judiciary's role in the DPA process in that:

the effect of DPAs has created the 'New Regulators' as the DoJ has fashioned for itself a new role of 'focusing more on prospective questions of corporate governance and compliance, and less on the retrospective question of the entity's criminal liability'. 113

Arguably, the DoJ may transgress the bounds of lawfulness so as to warrant judicial intervention to protect the integrity of the court. ${ }^{114}$ Vega was concerned that DPAs may ignore judicial opinion, that is, whether a court would agree with the agreement reached between the regulator and a defendant. ${ }^{115}$ The role of the judge appears to rubber-stamp the settlement, without inquiring into the legal basis for the DPA including whether it would tailor the offence more accurately. ${ }^{116}$ It constitutes a challenge of deploying a precision instrument to resolve allegations of corporate bribery. ${ }^{117}$

Few statutes lay down with precision the judiciary's role with regard to DPAs. ${ }^{118}$ Steinzor argued that:

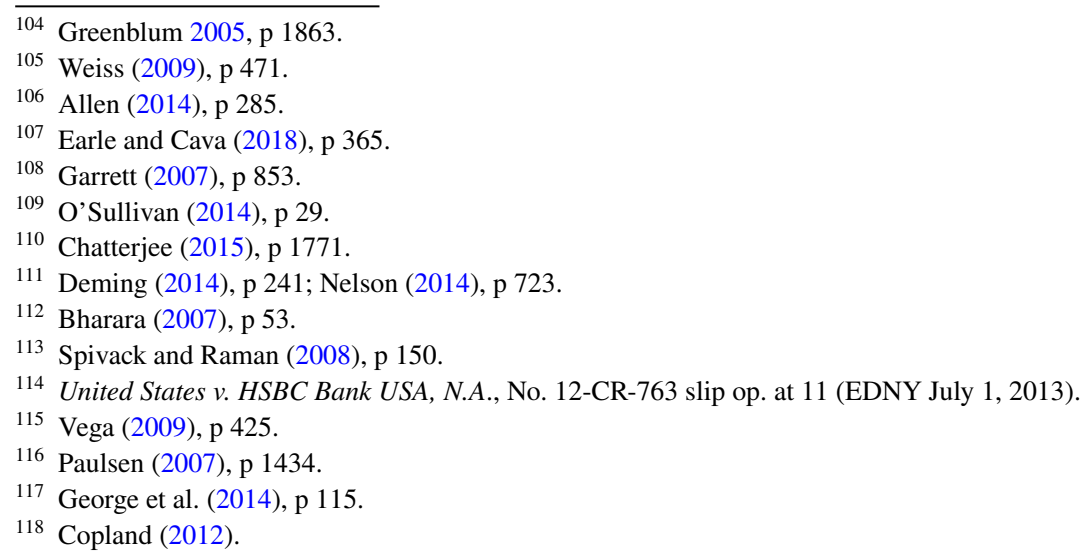


once prosecutors and a corporate defendant put a DPA before the court, they have irreversibly injected the court's supervisory authority into the process, effectively conceding that the court may approve or reject the agreement. ${ }^{119}$

Federal Rule of Criminal Procedure 7 requires that felony charges be brought against a defendant by a grand jury indictment. The protocol typically necessitates some judicial involvement in the DPA process, at least in accepting the waiver of indictment. ${ }^{120}$ A substantive gatekeeper role may be assumed under both Rule 11 of the Federal Rules of Criminal Procedure and the US Sentencing Guidelines, ${ }^{121}$ despite the fact that the latter does not provide clear authority for the court to approve or reject DPAs. ${ }^{122}$ In view of an argument that the agreements should be filed in court and be subject to its oversight, ${ }^{123}$ a commentator remarked that:

the role of the judge is not only a neutral adjudicator defending corporate offenders vulnerable to collateral consequences, but also a fiduciary for constituencies otherwise unrepresented in corporate deferral process and potentially vulnerable to negative externalities. ${ }^{124}$

The parties are under pressure to subject their DPA to the legitimate exercise of the court's authority. ${ }^{125}$ Consistent with the increased judicial supervision of SEC settlements, courts appear to be overseeing decisions to reach DPAs. ${ }^{126}$ In November 2011, Judge Rakoff rejected a \$285 million settlement between the SEC and Citicorp, and held that it was neither reasonable, nor fair, nor adequate, nor in the public interest. ${ }^{127}$ After all, the judiciary has an indispensable role to play in examining DPAs to ensure they are in the interests of justice. ${ }^{128}$ In $U S$ v. HSBC, Judge Gleeson invoked the federal court's traditional supervisory authority and held that the court should use the supervisory power to protect the integrity of judicial proceedings. ${ }^{129}$ This was echoed by Wilt in that: "there shall be public scrutiny of the process, the public will know what wrongdoing has taken place and the sanctions for it, including any penalty that has been paid'. ${ }^{130}$ It remains to be seen whether the tightened

\footnotetext{
119 Steinzor (2014), pp 253-273.

120 Wilt (2016), p 61.

121 Federal Rules of Criminal Procedure 11(b)(1)-(3); Garrett (2007), p 853.

122 Golumbic and Lichy (2014), p 1293.

123 Deming (2014), p 241; Nelson (2014), p 723.

124 Greenblum (2005), p 1863.

125 Alexander and Cohen (2015), p 537.

126 Pollack and Reisinger (2014), p 121.

127 Hubbell (2014), p 373.

128 Golumbic and Lichy (2014), p 1293.

129 United States of America v. HSBC Bank U.S.A., N.A. and HSBC Holdings Plc, Case No. 1:12cr763, US District Court for the Eastern District of New York, 12 November 2012.

130 Wilt (2016), p 61.
} 
judicial control would override the transparency and accountability concerns that have proliferated in the US. ${ }^{131}$

\subsection{More Prominent Judicial Oversight under the DAPs in the UK}

The UK Crime and Courts Act 2013 (CCA 2013) received Royal Assent on 23 April 2013, of which the DPA is addressed in Schedule 17 to assist prosecutors in combating corporate criminal offences. ${ }^{132}$ As a part of English law for the first time, CCA 2013 allows enforcement agencies to employ DPAs to resolve criminal allegations against corporations. ${ }^{133}$ It represents a milestone in antibribery, since courts, legislators and prosecutors have long exhibited scepticism about the extent to which the UK should transplant the US-style enforcement tool. ${ }^{134}$ The Fraud, Bribery and Money Laundering Offences Definitive Guideline provided for the first time a framework for the sentencing of corporate offenders in the UK. ${ }^{135}$ The Guideline was issued to facilitate the application of DPAs with financial penalties being taken into consideration. It is worth examining whether the earlier judicial involvement can be well justified in order for DPAs to work effectively in the UK.

MNCs consider the BA 2010 to be the toughest anti-bribery law in the world. An entity will be subject to criminal liability if an associated person commits bribery on its behalf, ${ }^{136}$ whereby the entity has failed to maintain adequate procedures in place. ${ }^{137}$ This approach once again reflects the UK's conventional jurisprudential philosophy that ex ante efforts are given considerable weight, compared with the procedural control and ex post resolution. Under BA 2010, prosecutors do not have to demonstrate mens rea on the part of the company. ${ }^{138}$ Potential penalties include unlimited fines, and even debarment from public procurement contracts, while individuals could face up to 10 years imprisonment. ${ }^{139}$ Differing from their US counterparts, UK prosecutors must seek judicial approval to commence initial negotiations. ${ }^{140}$ A settlement would not be entered into, were it not in the public interest. ${ }^{141}$ The public-interest test simply requires the prosecutor to ensure that the public interest would not be abused by a DPA in lieu of prosecution. ${ }^{142}$ The rationale is based on whether DPAs are in the interest of justice and whether the proposed terms are

\footnotetext{
131 Greenblum (2005), p 1863.

132 Crime and Courts Act 2013, s. 45.

133 Rubenfeld (2012).

134 Rose (2015a), § 38.

135 The UK Sentencing Council, Fraud, Bribery and Money Laundering Offences Definitive Guideline (effective from 1 October 2014), https://www.sentencingcouncil.org.uk/wp-content/uploads/Fraud_bribe ry_and_money_laundering_offences_-_Definitive_guideline.pdf.

136 BA 2010, s. 7(1)(a), (b).

137 BA 2010, s. 7.

138 Warin, Falconer and Diamant (2010), p 1.

139 BA 2010, s. 6.

140 SFO, DPA 2014, § 10; Mazzacuva (2014), p 249.

141 SFO, DPA 2014, $\$ 2.5$.

142 SFO, DPA 2014, § 1.2 (ii).
} 
fair, reasonable and proportionate to the offence. ${ }^{143}$ The judicial authorities make their decisions upon a rigorous evaluation. ${ }^{144}$ This implies that the self-disclosure of bribery will no longer predispose the SFO to civil remedies. ${ }^{145}$ According to Lord Justice Thomas:

it would be inconsistent with basic principles of justice for the criminality of corporations to be glossed over by a civil as opposed to a criminal sanction. ${ }^{146}$

In formalising a DPA, a preliminary private hearing is required to be held before a judge. ${ }^{147}$ The final hearing will be held in open court and the final agreement will be published. ${ }^{148}$ If the judge plays the role of the fiduciary, he/she should ensure that the use of DPAs is not to be abused. ${ }^{149}$

\subsection{DPAs: A Comparative Perspective}

The court plays a more prominent supervisory role under the UK DPA regime than in the US equivalent. ${ }^{150}$ There is substantive involvement by the judiciary at an initial stage, while the judiciary in the US plays a limited role upon the final draft of DPAs. There seems to be a clear divergence between the judicial attitudes towards DPAs. In scope, the US DoJ has substantial latitude in the types of crimes that DPAs may resolve, whereas Schedule 17 limits UK DPAs to mostly economic crimes. ${ }^{151}$ The DPA law allows the UK judiciary to play its role at an earlier stage while its US counterparts tend to become involved relatively later in the proceedings and on an ad hoc basis. In view of procedural control, the UK statutory regime and DPA Code set forth a more formalised process and provide a clearer roadmap for implementation. ${ }^{152}$ The DoJ has discretion to determine whether there is a breach of DPAs, while the Crown Court assumes this role under Schedule 17 with such determinations to be made on the basis of a balance of probabilities. ${ }^{153}$ The SFO encourages compliance, which is labelled as a twofold enforcement approach. ${ }^{154}$ This is consistent with the UK's long-standing focus on ex ante internal governance through fostering ethical corporate behaviour. In the US, sophisticated court and litigation systems are primarily relied upon, which is in line with its long-standing ex post

\footnotetext{
143 Crime and Courts Act 2013, Schedule 17, §§ 7(1)-(6).

144 Nelson (2014), p 723.

145 Mazzacuva (2014), p 249.

${ }^{146} R$ v. Innospec Limited, Sentencing Remarks of Lord Justice Thomas (26 March 2010), § 38.

147 Crime and Courts Act 2013, Schedule 17 Deferred Prosecution Agreements, $\S ~ 7(4), 8(5), 10(5)$.

148 UK Ministry of Justice, Deferred Prosecution Agreements-Response to Consultation CP(R)18/2012

(23 October 2012), https://www.gov.uk/government/uploads/system/uploads/attachment_data/file/23600 0/8463.pdf.

149 Greenblum (2005), p 1863.

150 Mazzacuva (2014), p 249.

151 Fisher et al. (2013), p 159.

152 Warin (2013).

153 Crime and Courts Act 2013, Schedule 17 Deferred Prosecution Agreements, § 9(1), (2).

154 Monteith (2011), p 111
} 
resolution. Furthermore, vicarious liability sets the threshold for prosecuting corporations at a lower level than in the UK. ${ }^{155}$ Corporations in the US are more inclined to cooperate with enforcement authorities so as to avoid potential prosecution. ${ }^{156}$ As such, it is not appropriate for DPAs, at least in their current form, to be simply transplanted into the UK judicial system. ${ }^{157}$

\section{Level the International Playing Field: Is a Single Global Settlement Viable?}

MNCs face an increasing risk of multiple sanctions across jurisdictions arising from the same conduct, ${ }^{158}$ which makes it enormously challenging for them to reach a global settlement. ${ }^{159}$ The companies in question may find that they can no longer rely on the defence of 'neither admit nor deny' for reduced penalties. ${ }^{160}$ The case of Siemens serves as a typical example whereby it has suffered significant financial and reputational damage from prosecutions in both Germany and the US. ${ }^{161}$ Ideally, MNCs would be in a better position to resolve their issues through a single global settlement with all relevant regulators. ${ }^{162}$ The adoption of DPAs makes it feasible for the SFO to discuss global resolutions with its foreign counterparts. In principle, defendants can seek to enter into joint settlements with both the UK and the US authorities, a model which helps to create a roadmap for a global settlement. ${ }^{163}$

\subsection{Cross-Jurisdictional Settlements}

If a global settlement through DPAs could be agreed upon this would potentially be conducive to facilitating negotiations between jurisdictions. MNCs are likely subject to multiple anti-bribery sanctions that are sometimes inconsistent. ${ }^{164}$ For instance, an ultimate resolution of a case will have to be approved by both the US and UK

\footnotetext{
155 Wells (2015), pp 59-80.

156 Arlen (2016), p 191.

157 UK Ministry of Justice, Deferred Prosecution Agreements-Response to Consultation CP(R)18/2012

(23 October 2012), https://www.gov.uk/government/uploads/system/uploads/attachment_data/file/23600 0/8463.pdf.

158 Bhojwani (2012), p 66.

159 Holtmeier (2015), p 493.

160 Buell (2011), p 87.

161 SEC, SEC Charges Siemens AG for Engaging in Worldwide Bribery (15 December 2008), http:// www.sec.gov/news/press/2008/2008-294.htm; DoJ, Siemens AG and Three Subsidiaries Plead Guilty to Foreign Corrupt Practices Act Violations and Agree to Pay $\$ 450$ Million in Combined Criminal FinesCoordinated Enforcement Actions by DOJ, SEC and German Authorities Result in Penalties of \$1.6 Billion (15 December 2008), http://www.justice.gov/opa/pr/2008/December/08-crm-1105.html.

162 Garrett (2011), p 1775.

163 Stocker and Keith (2013).

164 Davis (2016), p 57.
} 
judicial and enforcement agencies. As discussed earlier, the SFO will not be able to participate in global settlements unless there is a DPA approved by the court. ${ }^{165}$

\subsubsection{R v. Innospec}

In 2010, the UK and the US pursued criminal cases against Innospec Inc., a Delaware company, and its British subsidiary, Innospec Ltd. ${ }^{166}$ The SFO's case was developed resulting from a referral by the DoJ to the SFO, and both settlements were entered into on the same day. ${ }^{167}$ The DoJ prosecuted Innospec Inc. for bribery taking place in Iraq, so did the SFO relating to Indonesia. ${ }^{168}$ The DoJ entered into a DPA with Innospec and the SFO attempted to enter a plea agreement to settle charges for the company's overseas bribery. ${ }^{169}$ The enforcement authorities and Innospec negotiated a global settlement designed to penalise Innospec, but meanwhile attempted to prevent its insolvency. ${ }^{170}$ Innospec represented that it could only afford to pay $\$ 40.2$ million, and finally $\$ 14.1$ million was paid to the DoJ, \$11.2 million to the SEC, and \$2.2 million to the Office of Foreign Assets Control (OFAC). ${ }^{171}$ In addition, it agreed to pay the SFO $\$ 12.7$ million, of which $\$ 6$ million was paid as a civil penalty. ${ }^{172}$ The legal basis of the settlement between Innospec and the SFO has been challenged. ${ }^{173}$ Lord Justice Thomas nearly rejected the settlement due to a lack of judicial oversight concerning its terms, but then held that:

[i]t will rarely be appropriate for criminal conduct by a company to be dealt with any means of a civil recovery order [...] agreements to set a criminal penalty prior to a court hearing were not permissible under the laws. ${ }^{174}$

In the furtherance of his position, he continued that the court has a duty to 'rigorously scrutinise in open court in the interests of transparency and good governance based on a plea to see whether it reflects the public interest' ${ }^{175}$

The case of Innospec highlights the difficulties arising from different opinions between the SFO as the 'regulator' and the courts as the 'judicature'. ${ }^{176}$ The SFO's

\footnotetext{
165 Makinwa and Søreide (2018).

${ }^{166} R$ v. Innospec Limited (2010) Ew Misc 7 (EWCC); United States v. Innospec Inc., No. 1:10-cr-00061 (D.D.C. March 18, 2010).

167 Alderman (2014), pp 17-18.

168 SFO, Innospec Limited Prosecuted for Corruption by the SFO (18 March 2010).

169 Boutros and Funk (2012), p 259.

170 Ernst \& Young (2016).

171 United States v. Innospec Inc., No. 1:10-cr-00061 (D.D.C. March 18, 2010) 4.

172 SFO, Four Sentenced for Role in Innospec Corruption (4 August 2014), https://www.sfo.gov. uk/2014/08/04/four-sentenced-role-innospec-corruption/.

173 Mazzacuva (2014), p 249.

174 Lord Justice Thomas's Innospec Sentencing Remarks, § 38, http://www.judiciary.gov.uk/Resources/ JCO/Documents/Judgments/sentencing-remarks-thomas-1j-innospec.pdf.

175 Lord Justice Thomas's Innospec Sentencing Remarks, §§ 26-27; Daniel, Bacarese and Hatchard (2011), pp 222-225.

176 Horder and Alldridge (2013), pp 219-225.
} 
approach of fostering self-disclosure faces considerable challenges. ${ }^{177}$ There is little incentive to self-report bribery due largely to the high risk that the court may not accept a settlement agreed with the SFO. If the judiciary did not agree to the proposed arrangement with the SFO, ${ }^{178}$ the alleged entity could place itself in a rather disadvantageous position because of an admission of guilt. ${ }^{179}$ It is the first case where a global settlement has been sought in respect of concurrent criminal proceedings by the two primary jurisdictions. ${ }^{180}$ The fact that the conduct encompassed in each arrangement differed from the other undermines deeper collaboration between the two enforcement authorities. The resolution also paves the way for exploring how to coordinate the application of the double jeopardy doctrine, which will be examined in the following part. Thomas LJ's Sentencing Remarks reflect the divergences between the two jurisdictions. ${ }^{181}$ This indicates that the judiciary in the US is more inclined to accept such pleas than its UK counterpart. Innospec demonstrates differing ways in which it has linked courts in separate jurisdictions. ${ }^{182}$ The judicial roles in global settlements need to be refined in order for DPAs to be more viable. ${ }^{183}$ It remains uncertain how global settlements could be achieved given that a DPA in the UK does not offer a guarantee against prosecution in another jurisdiction. ${ }^{184}$ There clearly needs to be a stronger international consensus in this regard. ${ }^{185}$

\subsubsection{ICBC Standard Bank plc}

Despite the challenges, the MNCs in question are expected to cooperate with the SFO at an early stage. Under the terms of the DPA, the charges against ICBC Standard were suspended for 3 years. The terms of the DPA were ratified at a public hearing on 30 November 2015 before Lord Justice Leveson, under which ICBC Standard agreed to pay US\$32 million. ${ }^{186}$ On the same day, the SEC imposed a penalty of US\$4.2 million on the bank in a separate DPA. ${ }^{187}$

The bank's extensive cooperation was credited with having led the SFO and the court to approve the DPA, including the prompt self-disclosure of its own internal investigation. ${ }^{188}$ This is the first case in which the SFO has showed its teeth against an entity for violating Section 7 under BA 2010. ${ }^{189}$ In terms of internal governance,

\footnotetext{
$\overline{177} R$ v. Innospec Limited [2010] Ew Misc 7 (EWCC).

178 Mazzacuva (2014), p 249.

179 Dunst, Diamant and Kung (2011), p 257.

180 Boutros and Funk (2012), p 259.

181 Warin et al. (2018).

182 Lord (2014), p 100; Pacini (2012), p 545.

183 Xiao (2013), p 233.

184 Lord (2014), p 100.

185 Boutros (2013), p 43.

186 Serious Fraud Office v. ICBC Standard Bank plc, Case No: U20150854 (30 November 2015).

187 SEC, Standard Bank to Pay \$4.2 Million to Settle SEC Charges (Washington D.C., 30 November 2015), https://www.sec.gov/news/pressrelease/2015-268.html.

188 Serious Fraud Office v. ICBC Standard Bank plc, Case No: U20150854 (30 November 2015), § 27.

189 SFO, SFO Agrees First UK DPA with Standard Bank (30 November 2015), https://www.sfo.gov. uk/2015/11/30/sfo-agrees-first-uk-dpa-with-standard-bank/.
} 
the use of DPAs incentivises ethical conduct, and bona fide cooperation will likely convince an enforcement authority to address the offence in lieu of a criminal prosecution. ${ }^{190}$ Given the extraterritorial nature of BA 2010, the case has a far-reaching impact on companies which face exposure to liability for bribery by their associated persons extraterritorially. ${ }^{191}$

\subsubsection{GSK \& Rolls-Royce}

DPAs are designed to be a tool that seeks to achieve the goals whilst being transparent, clear and consistent. ${ }^{192}$ GlaxoSmithKline (GSK) paid the US SEC \$20 million to settle FCPA violations without admitting or denying the SEC's findings on 30 September 2016. ${ }^{193}$ In January 2017, Rolls-Royce paid $£ 497.25$ million and entered into a DPA with the SFO to settle allegations of wrongdoing. ${ }^{194}$ The SFO dropped investigations into Rolls-Royce and GSK on 22 February 2019, ${ }^{195}$ which has given rise to criticism as to whether the interests of justice have been served. The SFO's decision casts doubts about the viability of DPAs and the effectiveness of its investigatory powers. It raises a pertinent question about the purpose of DPAs, which undermines considerably the credible threats against both those powerful MNCs and their top executives. Given the SFO's low prosecution rate, MNCs' incentive to selfreport will be compromised. ${ }^{196}$ The SFO's dropping of its investigations potentially has significant implications for how those powerful MNCs' crimes will be prosecuted in the UK, which may also trigger criticisms over the integrity of the DPA process. One has legitimate concerns as to whether the phenomenon of 'too big to prosecute' exists in the UK's anti-bribery campaign.

\subsection{The Doctrine of Double Jeopardy and Deferred Prosecution Agreements}

The DPA, in theory, is likely to result in follow-on investigations by other regulators as well as civil lawsuits by some involved stakeholders. ${ }^{197}$ Bribery allegations

\footnotetext{
190 Xiao (2013), p 233.

191 Ross (2012), p 445.

192 UK Ministry of Justice (MoJ), Consultation on a New Enforcement Tool to Deal with Economic Crime Committed by Commercial Organisations: Deferred Prosecution Agreements (Consultation Paper CP9/2012), https://assets.publishing.service.gov.uk/government/uploads/system/uploads/attachment _data/file/236065/8348.pdf.

193 SEC, GlaxoSmithKline Pays \$20 Million Penalty to Settle FCPA Violations (Administrative Proceeding File No. 3-17606, 30 September 2016), https://www.sec.gov/litigation/admin/2016/34-79005 -s.pdf.

194 SFO, SFO Completes $£ 497.25 m$ Deferred Prosecution Agreement with Rolls-Royce PLC (17 January 2017), https://www.sfo.gov.uk/2017/01/17/sfo-completes-497-25m-deferred-prosecution-agreementrolls-royce-plc/.

195 SFO, SFO Closes GlaxoSmithKline Investigation and Investigation into Rolls-Royce Individuals (22 February 2019), https://www.sfo.gov.uk/2019/02/22/sfo-closes-glaxosmithkline-investigation-and-inves tigation-into-rolls-royce-individuals/.

196 Baker (2019).

197 Bulovsky (2019), p 549.
} 
often trigger concurrent proceedings in multiple jurisdictions based upon one single occurrence, which could cause a potential clash between DPAs and the risk of double jeopardy. ${ }^{198}$ One argument is that the integrity of the judicial system could be furthered through duplicative punishments. ${ }^{199}$ In both theory and the real world, there is little solid evidence to support this approach. It remains unclear as to whether multiple penalties serve the interests of justice. On the contrary, there have been comprehensive studies exploring how to proportionately and harmoniously address duplicative and multiple prosecutions of the same unlawful conduct. The prohibition of double jeopardy bars repeated prosecutions for the same conduct that originates from the doctrine of res judicata. ${ }^{200}$ With regard to cross-border bribery prosecutions, it remains a conundrum to protect the entity's right not to be tried twice for the same offence. ${ }^{201}$ The risk of facing multiple prosecutions creates a disincentive for companies to self-disclose potential bribery to enforcement agencies. $^{202}$ In this vein, the expansion of corporate offences has increased the theoretical complexity of applying the double jeopardy protection. ${ }^{203}$

A French court has applied the doctrine of double jeopardy in attempting to address the interaction of DPAs between jurisdictions. ${ }^{204}$ The case concerned an allegation of bribery relating to the United Nation's Iraqi Oil for Food programme (OFF). ${ }^{205}$ On 18 June 2015, a criminal court in Paris acquitted 14 companies on charges of active bribery in the same context. ${ }^{206}$ Four French companies had entered into DPAs with the US Department of Justice (DoJ), under which the entities admitted to making 'kickback' payments to the Iraqi state when dealing with the OFF. ${ }^{207}$ Initially, the French enforcement authorities proposed to prosecute them on the basis of the same conduct. Afterwards, the Paris Criminal Court relied on the doctrine of double jeopardy enshrined in the International Covenant on Civil and Political Rights (ICCPR). ${ }^{208}$ The Court then ruled that the DPAs entered into with the US authorities relating to the same offence barred a criminal conviction in France on the basis of the ne bis in idem principle. ${ }^{209}$ Procedurally, this decision broadens the

\footnotetext{
198 Claude (2015).

199 Owsley (2003), p 765.

200 US CONST. amend. V. '[N]or shall any person be subject for the same offence to be twice put in jeopardy of life or limb'.

201 Davis (2016), p 57.

202 Bhojwani (2012), p 66.

203 'Corporate Crime: Regulating Corporate Behaviour through Criminal Sanctions Developments in the Law', Harv. Law Rev. 92(6):1227-1375 (1979).

204 Davis (2016), p 57.

205 'The United Nations Oil-for-food Program: Issues of Accountability and Transparency: Hearing before the Committee on International Relations, House of Representatives' $\left(108^{\text {th }}\right.$ Congress, $2^{\text {nd }}$ Session, 28 April 2004).

206 Tokar (2015).

207 Otterman (2005).

208 ICCPR Art. 14(7): '[N]o one shall be liable to be tried or punished again for an offence for which he has already been finally convicted or acquitted in accordance with the law and penal procedure of each country.'

209 Boutros and Funk (2012), p 259.
} 
scope of the rule against double jeopardy, given that a DPA is not a judgment concluding a trial hearing, but rather an agreement between enforcement authorities and the entities in question. ${ }^{210}$ Similarly, the UK SFO and the US DoJ have actively collaborated on global settlements with MNCs. In April 2011, DePuy entered into a global settlement agreement which included a DPA with the DoJ and a civil recovery order with the SFO. ${ }^{211}$ The company had pleaded guilty to bribery offences in the US, which virtually deprived the SFO of its legal basis on which the agency could rely in order to prosecute the same misconduct. Applying the principle of double jeopardy, a prosecution in the UK was withdrawn. ${ }^{212}$ The rationale for this lies in the fact that a DPA has the same legal character as a formally-concluded prosecution and the SFO's investigation was based on the same facts. ${ }^{213}$ The doctrine of double jeopardy in the US is more limited than that in the UK, ${ }^{214}$ that is, it would not preclude a US prosecution had a DPA been obtained in the UK. ${ }^{215}$ In practice, however, it is likely that the SFO and DoJ are allowed to enter into separate DPAs based on distinct facts, with each settlement concentrating on a different jurisdiction. ${ }^{216}$

\subsection{Global Collaboration}

Every relevant jurisdiction ought to avoid a disproportionate enforcement of laws by multiple enforcement agencies in accordance with the principle of equity. ${ }^{217}$ Otherwise, MNCs would be deprived of certainties concerning their proceedings and likely be left with inconsistences. Although the OECD Convention requests the signatory nations to coordinate concurrent proceedings, ${ }^{218}$ the non-legally binding provision renders an enormous gap during its implementation. One of the substantial challenges is that some sovereign states do not recognise the double jeopardy doctrine for cross-jurisdictional settlements. Some jurisdictions afford no double jeopardy protection regardless of whether a defendant has already been prosecuted by a foreign state. ${ }^{219}$ A failure to achieve in-depth coordination will inevitably result in breaching the double jeopardy doctrine. As such, anti-bribery enforcement authorities should arguably seek to collaborate more effectively in cross-border cases. Nevertheless, there is no viable answer to an inquiry about how an MNC can be

\footnotetext{
210 Arlen (2016), p 191.

211 United States v. DePuy, Inc., Case No. 11-cr-099 (D.D.C., April 8, 2011), https://www.justice.gov/ criminal/fraud/fcpa/cases/depuy.../04-08-11depuy-dpa.pdf; SFO, DePuy International Limited Ordered to Pay $£ 4.829$ million in Civil Recovery Order (8 April 2011).

212 Holtmeier (2015), p 493.

213 Oduor et al. (2013), pp 101-120.

214 Coffin (2010), p 771.

215 George et al. (2014), p 115.

216 OECD (2019).

217 Hessick and Hessick (2011), p 45.

218 OECD Convention on Combating Bribery of Foreign Public Officials in International Business Transactions Art. 4(3). 'When more than one Party has jurisdiction over an alleged offence [...] the Parties shall $[\ldots]$ consult with a view to determining the most appropriate jurisdiction for prosecution.'

219 Colangelo (2009), p 769.
} 
protected from prosecution by multiple jurisdictions. ${ }^{220}$ It is imperative that the challenge is dealt with at an international level where efficient coordination can be ensured and the asymmetry of information can be mitigated. ${ }^{221}$ The government should coordinate with foreign jurisdictions seeking to resolve a case where an MNC faces duplicative or even multiple investigations for the same offence. ${ }^{22}$

A multinational entering into a DPA in the context of a cross-border investigation expects a coordinated global settlement within a reasonably short period. ${ }^{223}$ Thus, the firm will benefit from minimising negative publicity and a potential adverse impact on its stock price. ${ }^{224}$ Preventing undue double jeopardy would therefore more likely result in efficient resolution and consistency.

\section{The Role of Corporate Compliance Programmes under DPAs}

DPAs have the potential for companies to improve their compliance programmes, which also enables the parties involved to avoid the uncertainties that come with lengthy investigations. ${ }^{225}$ An effective compliance programme is a cornerstone in a modern governance and legal framework. DPAs enhance a system of incentives through encouraging companies to cooperate with enforcement agencies externally and to improve compliance mechanisms internally. ${ }^{226}$ As a requisite condition for DPAs, internal compliance must be based on a rigorous assessment of information, rather than being influenced by conflicts of interest. ${ }^{227}$ Notably, enforcement authorities often use imposed independent monitors to improve compliance quality, which helps to attenuate unintended dire consequences. ${ }^{228}$

\subsection{Two Tales of Compliance Programmes}

It is argued that DPAs can entail more efficacy and potentially facilitate compliance to tackle bribery. ${ }^{229}$ Given the tool's flexible use on an ad hoc basis, MNCs benefit greatly from an effective compliance programme. ${ }^{230}$ They receive credit in DPAs for

\footnotetext{
220 Adler (2014), p 448; Matthew (2013).

221 Horder and Alldridge (2013), pp 219-225.

222 US DoJ (2018).

223 Holtmeier (2015), p 493.

224 UK Ministry of Justice (MoJ), A New Enforcement Tool to Deal with Economic Crime by Commercial Organisations: Deferred Prosecution Agreements (10 July 2012), https://consult.justice.gov.uk/digit al-communications/deferred-prosecution-agreements/supporting_documents/deferredprosecutionagreem entsia.pdf.

225 Deming (2011), p 79.

226 Kaal and Lacine (2013), p 61.

227 SFO, DPA 2014.

228 Markof (2013), p 797.

229 Koehler (2010), p 907.

230 Stucke (2014), p 769.
} 
their ethical behaviour and internal control. ${ }^{231}$ The enforcement policy is to reward the entities for self-disclosure and genuine cooperation during the enforcement agencies' investigation. ${ }^{232}$ As the FCPA Guide articulates, the DoJ and the SEC consider the merits of a company's FCPA compliance programme when determining whether a DPA should be reached. ${ }^{233}$ Robust compliance measures can help to prevent serious offences from arising ex ante and mitigate the damage in the case of occurrence ex post. ${ }^{234}$

Tough as it is, putting adequate procedures in place constitutes an affirmative defence under BA 2010. ${ }^{235}$ In turn, the preventive measures alleviate the heavy financial burden placed on the SFO to undertake costly investigations. As Alderman said, the SFO's role seems to be shifting from a prosecutor to a regulator as it has developed a twofold approach to enforcement. ${ }^{236}$ Companies can receive reasonable credit for self-disclosure. In the case of Mabey and Johnson Ltd, ${ }^{237}$ the UK courts reached an American-style plea bargaining settlement, which demonstrates that the variable, such as self-reporting, compliance-building and the use of monitors can be rooted in a UK framework as well. ${ }^{238}$ These factors squarely characterise the key features of a DPA, and some approaches mirror the US Sentencing Guidelines' definition of an effective compliance programme. ${ }^{239}$ Koehler provided further insights that: 'the compliance undertakings required pursuant to a DPA are virtually identical in every enforcement action and have evolved into a compliance template'. ${ }^{240}$ It is noteworthy that a corporate compliance policy which satisfies the FCPA may not necessarily be sufficient for those criteria under Section 7 of BA 2010. ${ }^{241}$ In arguing whether DPAs can genuinely improve internal governance, Krawiec was concerned that:

the prosecutorial focus on governance will simply lead corporations to adopt best practices in name only, akin to how companies go through the motions of compliance without promoting legal obedience in fact. ${ }^{242}$

\footnotetext{
231 Hamann (2019), p 851.

232 FCPA Guidance, pp 55-60.

233 FCPA Guidance, p 56.

234 Paine (1994); Koehler (2012), p 609.

235 BA 2010, s. 7(2).

236 Richard Alderman (SFO Director), Speech (23 June 2010).

237 v. Mabey and Johnson Ltd (Crown Court at Southwark, 2009).

238 Regina v. Mabey and Johnson Ltd., No. T2009 7513 [2009] Southwark Crown Court; Serious Fraud Office, Mabey \& Johnson Ltd Sentencing (25 September 2009), http://www.sfo.gov.uk/press-room/lates t-press-releases/press-releases-2009/mabey--johnsonltd-sentencing-.aspx; Warin, Falconer and Diamant (2010), p 1.

239 The US Federal Sentencing Guidelines, 18 USCA $§ 8 B 2.1$.

240 Koehler (2012), p 609.

241 UK Ministry of Justice, The Bribery Act 2010 Guidance (March 2011), http://www.justice.gov.uk/ downloads/legislation/bribery-act-2010-guidance.pdf, '(i) Proportionate Procedures; (ii) Top Level Commitment; (iii) Risk Assessment; (iv) Due Diligence; (v) Communication; and (vi) Monitoring and Review'.

242 Krawiec (2003), p 487.
} 
As such, a strong framework needs to be built for further guidance on compliance. ${ }^{243}$ In exercising their discretion, enforcement authorities normally consider such factors as the nature of the offence, voluntary disclosure, a compliance programme and its effectiveness as well as remedial efforts. ${ }^{244}$ The DPA's Code of Practice underscores the need for effective internal compliance as the most crucial part during the negotiation of a settlement. ${ }^{245}$ A more sophisticated governance regime is expected along with efficient oversight by the monitor as well. ${ }^{246}$

DPAs often involve appointing an independent monitor within an entity. ${ }^{247}$ As an oversight mechanism, the device of monitorship has a theoretical appeal to assure compliance with the agreed terms and conditions of DPAs. ${ }^{248}$ Garrett sees this as useful as part of a package to underpin the DPA regime:

the overall approach requires comprehensive compliance programmes, including independent monitors, detailed injunctive changes of policy and practice, training programs, auditing, data collection and cooperation with the DoJ. ${ }^{249}$

The objective to make use of monitors does not merely ensure that the law will not be violated, but it enhances internal compliance ex ante for the sake of prevention. ${ }^{250}$ Otherwise, violations could go undetected. ${ }^{251}$ Prosecutors regard monitorships as an integratory element in ensuring the efficacy of DPAs. ${ }^{252}$

However, the problem lies in how to realistically ensure the monitor's independence from the entity in which it has been embedded, possibly for many years, while still maintaining an objective approach as far as the enforcement authorities are concerned. $^{253}$

\subsection{Foster a Compliance Culture}

There is a culture of compliance being bred with the use of DPAs. ${ }^{254}$ Presumed as a preliminary step to judicial proceedings, a strong internal governance regime is helpful to deal with the liability issue on an ad hoc basis. ${ }^{255} \mathrm{~A}$ well-designed DPA has the potential to entail a positive change in compliance culture by promoting companies to address bribery proactively. ${ }^{256}$ As Breuer said:

\footnotetext{
243 Morgan (2015).

244 SFO, DPA 2014.

245 FCPA Guidance, pp 56-67.

246 SFO, DPA 2014, §§ 7.11 \& 7.22.

247 SFO, DPAs New Guidance.

248 Khanna and Dickinson (2007), p 1713.

249 Garrett (2007), p 853.

250 Ford and Hess (2009), p 679.

251 Cunningham (2014), p 1.

252 Barkow and Barkow (2011), pp 226-248.

253 Deming (2014), p 241; Nelson (2014), p 723.

254 Spivack and Raman (2008), p 150.

255 Gruner (2007), pp 279-306.

256 Griffin (2011), p 110.
} 
DPAs have had a truly transformative effect [...] on corporate culture across the globe [...] [resulting in] unequivocally far greater accountability for corporate wrongdoing — and a sea change in corporate compliance efforts. ${ }^{257}$

In order to achieve this strategy, it is imperative for an MNC to have sophisticated compliance measures in place. In view of procedural control, it is similarly significant to introduce a periodical evaluation of the implementation. If necessary, some back-up schemes and associated adjustment alternatives should be established in advance. The DPA regime can be fine-tuned to achieve future deterrence goals through rewarding cooperation and attenuating damages. ${ }^{258}$ Companies are encouraged to engage in improving ethical behaviour as a routine. It is equally essential that companies should be incentivised to self-report potential violations, to provide feasible remedial measures and to undertake adequate governance in order to prevent repeated bribery.

\section{Conclusion}

DPAs have been designed to allow prosecutors and the courts to address bribery more effectively. This enforcement tool is regularly used to mitigate collateral consequences while promoting accountability, deterrence and remediation. Moreover, DPAs serve as a sensible valve in response to an aggressive prosecutorial regime and to save precious judicial resources.

Embodying flexibility and pragmatism into law, DPAs potentially incentivise companies to self-report wrongful conduct and cooperate bona fide with enforcement authorities. The mechanism transplanted into the UK, in principle, enables companies to engage with the SFO at an early stage to achieve a better settlement. More significantly, those companies in question should take proactive steps to remediate the concern, to address deeply-rooted causes and to avoid potential repeated behaviour. Through this alternative tool to prosecution, the SFO integrates itself more effectively into the global campaign against corruption. Uncertainty remains, however, about the extent to which the DPA system will change the enforcement landscape. Given that the SFO does not ultimately control the outcome of a DPA negotiation, the resulting uncertainty makes it a paramount challenge for MNCs to enter into global settlements. It takes time to see whether the UK version of DPAs will likewise prove effective in tackling bribery. In view of the SFO's recent contentious conclusion of the investigations in the cases of GSK and Rolls-Royce, the viability of DPAs has been cast further into doubt. It is too early to say whether DPAs will alter fundamentally the future landscape of the enforcement regime for antibribery and whose impact will be viable but only incrementally.

\footnotetext{
${ }^{257}$ Lanny Breuer, Speech at the New York City Bar Association (13 September 2012), http://www.justi ce.gov/criminal/pr/speeches/2012/crm-speech-1209131.html.

${ }^{258}$ FCPA Guidance, pp 56-60.
} 
Open Access This article is licensed under a Creative Commons Attribution 4.0 International License, which permits use, sharing, adaptation, distribution and reproduction in any medium or format, as long as you give appropriate credit to the original author(s) and the source, provide a link to the Creative Commons licence, and indicate if changes were made. The images or other third party material in this article are included in the article's Creative Commons licence, unless indicated otherwise in a credit line to the material. If material is not included in the article's Creative Commons licence and your intended use is not permitted by statutory regulation or exceeds the permitted use, you will need to obtain permission directly from the copyright holder. To view a copy of this licence, visit http://creativecommons.org/licen ses/by/4.0/.

\section{References}

Addady M (2016, October 7) Walmart rejects paying \$600 million settlement in bribery investigation. Fortune

Adler A (2014) Dual sovereignty, due process, and duplicative punishment: a new solution to an old problem. Yale Law J 124:448-483

Alderman R (2014) B20 Task Force on Improving Transparency and Anticorruption: development of a preliminary study on possible regulatory developments to enhance the private sector role in the fight against corruption in a global business context. 8 January 2014. https://www.aodv231.it/ images/image/Allegato\%201\%20-Preliminary_Study_v_2\%201.pdf. Accessed 5 Jan 2021

Alexander C, Cohen M (2015) The evolution of corporate criminal settlements: an empirical perspective on non-prosecution, deferred prosecution, and plea agreements. Am Crim Law Rev 52:537-594

Allen B (2014) Deferred prosecution agreements - a new weapon in the anti-fraud and corruption armoury? Gov Dir 66:285-287

Alschuler A (2009) Two ways to think about the punishment of corporations. Am Crim Law Rev 46:1359-1392

Anderson J, Waggoner I (2014) The changing role of criminal law in controlling corporate behaviour. RAND Corporation. http://www.rand.org/content/dam/rand/pubs/research_reports/RR400/RR412/ RAND_RR412.pdf. Accessed 16 Oct 2020

Arlen J (2016) Prosecuting beyond the rule of law: corporate mandates imposed through deferred prosecution agreements. J Leg Anal 8:191-234

Arlen J (2019) The potential promise and perils of introducing deferred prosecution agreements outside the U.S. NYU Law and Economics Research Paper No 19-29. 15 August 2019. https://papers.ssrn. com/sol3/papers.cfm?abstract_id=3428657. Accessed 5 Jan 2021

Arlen J, Kraakman R (1997) Controlling corporate misconduct: an analysis of corporate liability regimes. NY Univ Law Rev 72:687-779

Arlen J, Kahan M (2016) Corporate governance regulation through non-prosecution. Univ Chic Law Rev $84: 323-387$

Baker T (2019, February 22) DPAs in spotlight as SFO ends long-running Rolls-Royce and GSK investigations. Legal Business

Barkow A, Barkow R (2011) Prosecutors in the boardroom: using criminal law to regulate corporate conduct. New York University Press, New York

Beale SS (2009) A response to the critics of corporate criminal liability. Am Crim Law Rev 46:1481-1505

Bharara P (2007) Corporations cry uncle and their employees cry foul: rethinking prosecutorial pressure on corporate defendants. Am Crim Law Rev 44:53-114

Bhojwani R (2012) Deterring global bribery: where public and private enforcement collide. Columbia Law Rev 112:66-111

Bonneau J (2011) Combating foreign bribery: legislative reform in the United Kingdom and prospects for increased global enforcement. Columbia J Transnatl Law 47:365-410

Bourjaily G (2015) DPA DOA: how and why congress should bar the use of deferred and non-prosecution agreements in corporate criminal prosecutions. Harv J Legis 52:543-569

Boutros A (2013) Another bite at the apple: transnational crimes face repeat punishment. Litigation 39:43-46 
Boutros A, Funk M (2012) 'Carbon copy' prosecutions: a growing anticorruption phenomenon in a shrinking world. Univ Chic Leg Forum 2012:259-298

Braithwaite J (1982) Enforced self-regulation: a new strategy for corporate crime control. Mich Law Rev 80:1466-1507

Buell S (2011) Potentially perverse effects of corporate civil liability. In: Barkow A, Barkow R (eds) Prosecutors in the boardroom: using criminal law to regulate corporate conduct. New York University Press, New York, pp 87-109

Bulovsky AT (2019) Promoting predictability in business: solutions for overlapping liability in international anticorruption enforcement. Mich J Int Law 40:549-578

Chatterjee S (2015) Dangerous liaisons: criminalization of 'relationship hires' under the Foreign Corrupt Practices Act. Univ Pa Law Rev 163:1771-1804

Claude O (2015) Deferred prosecution agreements and the risk of double jeopardy in cross-border investigations. 22 October 2015. http://www.aoinvestigationsinsight.com/deferred-prosecution-agree ments-and-the-risk-of-double-jeopardy-in-cross-border-investigations. Accessed 20 Oct 2020

Coffee J (1981) No soul to damn: no body to kick: an unscandalized inquiry into the problem of corporate punishment. Mich Law Rev 79:386-459

Coffin K (2010) Double take: evaluating double jeopardy reform. Notre Dame Law Rev 85:771-808

Colangelo A (2009) Colonel double jeopardy and multiple sovereigns: a jurisdictional theory. Wash Univ Law Rev 86:769-857

Copland J (2012) The shadow regulatory state: the rise of deferred prosecution agreements. 14 May 2012. http://www.manhattan-institute.org/html/cjr_14.htm. Accessed 16 Oct 2020

Crespo AM (2018) The hidden law of plea bargaining. Columbia Law Rev 118:1303-1424

Cunningham L (2014) Deferred prosecutions and corporate governance: an integrated approach to investigation and reform. Fla Law Rev 66:1-86

Daniel T, Bacarese A, Hatchard J (2011) Corruption and misuse of public office. Oxford University Press, Oxford

Davis F (2016) International double jeopardy: U.S. prosecutions and the developing law in Europe. Am Univ Int Law Rev 31:57-101

Deming S (2011) The Foreign Corrupt Practices Act and the new international norms, 2nd edn. American Bar Association, Chicago

Deming S (2014) Anti-bribery laws in common law jurisdictions. Oxford University Press, Oxford

Diskant EB (2008) Comparative corporate criminal liability: exploring the uniquely American doctrine through comparative criminal procedure. Yale Law J 118:126-176

US DoJ (2017) Deputy Attorney General Rosenstein delivers remarks at the 34th International Conference on the Foreign Corrupt Practices Act. 29 November 2017. https://www.justice.gov/opa/speec h/deputy-attorney-general-rosenstein-delivers-remarks-34th-international-conference-foreign. Accessed 16 Oct 2020

US DoJ (2018) Deputy Attorney General Rod Rosenstein delivers remarks to the New York City Bar White Collar Crime Institute. 9 May 2018. https://www.justice.gov/opa/speech/deputy-attorneygeneral-rod-rosenstein-delivers-remarks-new-york-city-bar-white-collar. Accessed 16 Oct 2020

Dunst L, Diamant M, Kung T (2011) Hot off the press: resetting the global anti-corruption thermostat to the UK Bribery Act. Bus Law Int 12:257-278

Earle B, Cava A (2018) Examining the JPMorgan 'princeling' settlement: insight into current Foreign Corrupt Practices Act (FCPA) interpretation and enforcement. Wash Univ Global Stud Law Rev $17: 365-410$

Ernst \& Young (2016) UK bribery digest fraud investigation \& dispute services, edn 9. July 2016. https:// na.eventscloud.com/file_uploads/82b3e53489b56a968c03bfe0e604caaa_EYUKBriberyDigest.pdf. Accessed 4 Jan 2021

Fisher J et al (2013) The global financial crisis: the case for a stronger criminal response. Law Financ Mark Rev 7:159-166

Ford C, Hess D (2009) Can corporate monitorships improve corporate compliance? J Corp Law 34:679-737

Gallo J, Greenfield D (2014) The corporate criminal defendant's illusory right to trial: a proposal for reform. Notre Dame J Law Ethics Public Policy 28:525-547

Garret B (2017) The public interest in corporate settlements. BC Law Rev 58:1483-1543

Garrett B (2007) Structural reform prosecution. Va Law Rev 93:853-957

Garrett B (2011) Globalized corporate prosecutions. Va Law Rev 97:1775-1875 
Garrett B (2016) Too big to jail: how prosecutors compromise with corporations. Harvard University Press, Cambridge

George S, Ward A, McGarry R (2014) Deferred prosecution agreements-in jeopardy of falling short? Bus Law Int 15:115-122

Gilchrist GM (2012) The expressive cost of corporate immunity. Hastings Law J 64:1-57

Golumbic C, Lichy A (2014) The 'too big to jail' effect and the impact on the justice department's corporate charging policy. Hastings Law J 65:1293-1344

Greenblum B (2005) What happens to a prosecution deferred? Judicial oversight of corporate deferred prosecution agreements. Columbia L Rev 105:1863-1904

Griffin LK (2011) Inside-out enforcement. In: Barkow A, Barkow R (eds) Prosecutors in the boardroom: using criminal law to regulate corporate conduct. New York University Press, New York, pp 110-131

Grossman DI (2016) Would a corporate death penalty be cruel and unusual punishment. Cornell J Law Public Policy 25:697-722

Gruner R (2007) Preventative fault and corporate criminal liability: transforming corporate organizations into private policing entities. In: Pontell H, Gruner R (eds) International handbook of white-collar and corporate crime. Springer Science and Business Media, New York, pp 279-306

Hamann S (2019) Effective corporate compliance: a holistic approach for the SEC and the DoJ. Wash Law Rev 94:851-886

Hasnas J (2007) Foreword to corporate criminality: legal, ethical and managerial implications. Am Crim Law Rev 44:1269-1278

Hessick CB, Hessick FA (2011) Double jeopardy as a limit on punishment. Cornell Law Rev 97:45-86

Holtmeier J (2015) Cross-border corruption enforcement: a case for measured coordination among multiple enforcement authorities. Fordham Law Rev 84:493-523

Horder J, Alldridge P (2013) Modern bribery law: comparative perspectives. Cambridge University Press, Cambridge

Hubbell D (2014) Judge Rakoff v. The Securities and Exchange Commission: are 'neither admit nor deny' settlement agreements in securities cases in the public interest? Transactions 15:373

Kaal W, Lacine T (2013) The effect of differed and non-prosecution agreements on corporate governance: evidence from 1993-2013. Bus Lawyer 70:61-120

Kaul P (2015) Admit or deny: a call for reform of the SEC's 'neither-admit-nor-deny' policy. Univ Mich J Law Reform 48:535-564

Kennedy C (1985) Criminal sentences for corporations: alternative fining mechanisms. Cal Law Rev 73:443-482

Khanna V (1996) Corporate criminal liability: What purpose does it serve? Harv Law Rev 109:1477-1534

Khanna V, Dickinson T (2007) The corporate monitor: the new corporate czar? Mich Law Rev 105:1713-1755

Koehler M (2010) The facade of FCPA enforcement. Geo J Int Law 41:907-1010

Koehler M (2012) Revisiting a Foreign Corrupt Practices Act compliance defense. Wis Law Rev 609-659

Krawiec K (2003) Cosmetic compliance and the failure of negotiated governance. Wash Univ Law Q $81: 487-544$

Lewis B, Woodward S (2014) Corporate criminal liability. Am Crim Law Rev 51:923-962

Lord N (2014) Responding to transnational corporate bribery using international frameworks for enforcement. Criminol Crim Justice 14:100-120

Macey J (1991) Agency theory and the criminal liability of corporations. Boston Univ Law Rev 71:315-340

Makinwa A, Søreide T (2018) Structured settlements for corruption offences towards global standards? Paris, OECD, December 2018. https://www.oecd.org/corruption/anti-bribery/IBA-Structured-Settl ements-Report-2018.pdf. Accessed 16 Oct 2020

Markof G (2013) Arthur Andersen and the myth of the corporate death penalty: corporate criminal convictions in the twenty-first century. Univ Pa J Bus Law 15:797-842

Matthew C (2013, September 5) Double jeopardy could bind SFO in potential Glaxo prosecution. Wall Street Journal

Mazzacuva F (2014) Justifications and purposes of negotiated justice for corporate offenders: deferred and non-prosecution agreements in the UK and US systems of criminal justice. J Crim Law 78:249-262

McLean N (2012) Cross-national patterns in FCPA enforcement. Yale Law J 121:1970-2012 
Miller M (2016) More than just a potted plant: a court's authority to review deferred prosecution agreements under the speedy trial act and under its inherent supervisory power. Mich Law Rev 115:135-170

Monteith C (2011) The Bribery Act 2010: part 3: enforcement. Crim Law Rev 2:111-121

Morgan B (2015) Compliance and cooperation. 20 May 2015. https://www.sfo.gov.uk/2015/05/20/compl iance-and-cooperation/. Accessed 4 Jan 2021

Nanda V (2011) Corporate criminal liability in the United States: is a new approach warranted? In: Pieth M, Ivory R (eds) Corporate criminal liability: emergence, convergence and risk. Springer, New York, pp 63-89

Nelson C (2014) Corporate compliance monitors are not superheroes with unrestrained power: a call for increased oversight and ethical reform. Geo J Legal Ethics 27:723-764

O'Sullivan J (2014) How prosecutors apply the federal prosecutions of corporations charging policy in the era of deferred prosecutions, and what that means for the purposes of the federal criminal sanctions. Am Crim Law Rev 51:29-56

Oded S (2017) Coughing up executives or rolling the dice: individual accountability for corporate corruption. Yale Law Policy Rev 35:49-86

Oduor JA et al (2013) Left out of the bargain settlements in foreign bribery cases and implications for asset recovery. World Bank Publications, Washington DC

OECD (2019) Resolving foreign bribery cases with non-trial resolutions settlements and non-trial agreements by parties to the Anti-Bribery Convention. https://www.oecd.org/daf/anti-bribery/Resolvingforeign-bribery-cases-with-non-trial-resolutions.pdf. Accessed 16 Oct 2020

Otterman S (2005) IRAQ: oil for sood scandal. 28 October 2005. https://www.cfr.org/backgrounder/iraqoil-food-scandal. Accessed 16 Oct 2020

Owsley DB (2003) Accepting the dual sovereignty exception to double jeopardy: a hard case study. Wash Univ Law Rev 81:765-800

Pacini C (2012) The Foreign Corrupt Practices Act: taking a bite out of bribery in international business transactions. Fordham J Corp Financ Law 17:545-589

Paine L (1994) Managing for organizational integrity. Harv Bus Rev. March-April 1994. https://hbr. org/1994/03/managing-for-organizational-integrity. Accessed 1 Oct 2020

Paulsen E (2007) Imposing limits on prosecutorial discretion in corporate prosecution agreements. NY Univ Law Rev 82:1434-1469

Perkel W (2003) The Foreign Corrupt Practices Act. Am Crim Law Rev 40:683-704

Pollack B, Reisinger AW (2014) Lone wolf or the start of a new pack: should the FCPA guidance represent a new paradigm in evaluating corporate criminal liability risks? Am Crim Law Rev $51: 121-128$

Pollard S (2014) Deferred prosecution agreements: a practical guide. 24 February 2014. https://www. lexology.com/library/detail.aspx?g=770a30c6-89b2-4f53-bf5e-ec996ffef9c7. Accessed 5 Jan 2021

Principato D (2014) Defining the 'sovereign' in dual sovereignty: does the protection against double jeopardy bar successive prosecutions in national and international courts? Cornell Int Law $\mathbf{J}$ 47:767-785

Reilly P (2015) Incentivizing corporate America to eradicate transnational bribery worldwide: federal transparency and voluntary disclosure under the Foreign Corrupt Practices Act. Fla Law Rev 67:1683-1733

Rose A (2015a) Public enforcement: criminal versus civil. In: Gordon J, Ringe W-G (eds) The Oxford handbook of corporate law and governance. Oxford University Press, Oxford, pp 946-960

Rose C (2015b) International anti-corruption norms: their creation and influence on domestic legal systems. Oxford University Press, Oxford

Ross LA (2012) Using foreign relations law to limit extraterritorial application of the Foreign Corrupt Practices Act. Duke Law J 62:445-485

Rubenfeld S (2012, October 24) UK to move forward with deferred prosecution agreements. Wall Street Journal

Schipani C, Liu J, Xu H (2016) Doing business in a connected society: the GSK bribery scandal in China. Univ Ill Law Rev 64:63-102

Spivack P, Raman S (2008) Regulating the 'new regulators': current trends in deferred prosecution agreements. Am Crim Law Rev 45:150-193

Steinzor R (2014) Why not jail? Industrial catastrophes, corporate malfeasance, and government inaction. Cambridge University Press, Cambridge

Stevenson D, Wagoner N (2011) FCPA sanctions: too big to debar? Fordham Law Rev 80:775-820 
Stocker T, Keith R (2013) DPAs: cross-border confusion? The Journal. http://www.journalonline.co.uk/ Magazine/58-6/1012706.aspx. Accessed 16 Oct 2020

Stucke M (2014) In search of effective ethics \& compliance programs. J Corp Law 39:769-832

Tillipman J (2012) A house of cards falls: why 'too big to debar' is all slogan and little substance. Fordham Law Rev Res Gestae 80:49-58

Tokar D (2015, June 22) French court rules that double jeopardy protections extend to U.S. DPAs. Global Investigations Review

Uhlmann D (2013) Deferred prosecution and non-prosecution agreements and the erosion of corporate criminal liability. Md Law Rev 72:1295-1344

Vega M (2009) The Sarbanes Oxley Act and the culture of bribery: expanding the scope of private whistleblower suits to overseas employees. Harv J Legis 46:425-501

Viswanatha A, Nassauer S (2017, May 9) U.S. asks Wal-Mart to pay \$300 million to settle bribery probe. Wall Street Journal

Vorenberg J (1981) Decent restraint of prosecutorial power. Harv Law Rev 94:1521-1573

Warin J (2013) Mid-year update on corporate deferred prosecution and non-prosecution agreements. Harvard Law School Forum on Corporate Governance and Financial Regulation. 24 July 2013. https ://corpgov.law.harvard.edu/2013/07/24/2013-mid-year-update-on-corporate-deferred-prosecutio n-and-non-prosecution-agreements/. Accessed 16 October 2010

Warin J, Boutros A (2007) Deferred prosecution agreements: a view from the trenches and a proposal for reform. Va Law Rev Brief 93:121-134

Warin J, Falconer C, Diamant M (2010) The British are coming! Britain changes its law on foreign bribery and joins the international fight against corruption. Tex Int Law J 46:1-72

Warin FJ et al (2018) Gibson Dunn offers update on corporate non-prosecution and deferred prosecution agreements. The CLS Blue Sky Blog, 27 July 2018. https://clsbluesky.law.columbia. edu/2018/07/27/gibson-dunn-offers-update-on-corporate-non-prosecution-and-deferred-prosecutio n-agreements/. Accessed 16 Oct 2020

Weiss D (2009) The Foreign Corrupt Practices Act, SEC disgorgement of profits and the evolving international bribery regime: weighing proportionality, retribution and deterrence. Mich J Int Law 30:471-514

Weissmann A (2007) A new approach to corporate criminal liability. Am Crim Law Rev 44:1319-1342

Weissman A, Newman D (2007) Rethinking corporate criminal liability. Ind Law J 82:411-451

Wells C (2015) Enforcing anti bribery laws against transnational corporations: a UK perspective. In: Hardi P, Heywood P, Torsello D (eds) Debates of corruption and integrity: perspectives from Europe and the US. Palgrave Macmillan, London, pp 59-80

Werle N (2019) Prosecuting corporate crime when firms are too big to jail: investigation, deterrence, and judicial review. Yale Law J 128:1366-1438

Wilt MP (2016) Who watches the watchmen? Accountability in federal corporate criminal prosecutions. Am J Crim Law 43:61-104

Xiao MY (2013) Deferred/non-prosecution agreements: effective tools to combat corporate crime. Cornell J Law Public Policy 23:233-253

Publisher's Note Springer Nature remains neutral with regard to jurisdictional claims in published maps and institutional affiliations. 